Article

\title{
Durable Homelessness: From Negotiations to Emulation
}

\author{
Kristina Carlsson Stylianides *, Verner Denvall and Marcus Knutagård \\ School of Social Work, Lund University, Sweden; E-Mails: kristina.carlsson_stylianides@soch.lu.se (K.C.S.), \\ verner.denvall@soch.lu.se (V.D.), marcus.knutagard@soch.lu.se (M.K.) \\ * Corresponding author
}

Submitted: 30 March 2021 | Accepted: 24 June 2021 | Published: 26 August 2021

\begin{abstract}
In recent decades, Sweden has seen extensive change in its housing policy, with emphasis shifting from "good housing for all" to marketisation and the supposed benefits of private ownership (Bengtsson, 2013; Grander, 2018). Consequently, Swedish society is now facing increasing homelessness rates, including whole new groups of social service clients due to housing shortages and people's difficulties accessing the housing market. This article examines the complexities emerging from diverging institutional frames and points specifically to a dividing line between those who can access housing independently and those who need support from the social services. The article describes how such a categorical division/dividing line is institutionalised in the organisation of the social services' work with homelessness and points to causes and effects of this situation. The case study is based on interviews and documents. The interviewees are staff from the municipal social services and the municipal public housing company. Our theoretical point of departure is Tilly's (1999) "categorical inequality," using exploitation, opportunity hoarding, emulation, and adaptation to explain how homelessness is (created and) maintained in our case study. The results show the dependency of social services on external actors and demonstrate the problematic consequences both for those referred to social services and for the practical work within them, including a requirement to stringently control clients. The results further show how it is possible for the social services to maintain collaboration with (public) housing companies at the same time as the most vulnerable clients are permanently denied housing.
\end{abstract}

\section{Keywords}

homelessness; social housing; social services

\section{Issue}

This article is part of the issue "Home- and Community-Based Work at the Margins of Welfare: Balancing between Disciplinary, Participatory and Caring Approaches" edited by Kirsi Juhila (Tampere University, Finland), Cecilia Hansen Löfstrand (University of Gothenburg, Sweden) and Johanna Ranta (Tampere University, Finland).

(C) 2021 by the authors; licensee Cogitatio (Lisbon, Portugal). This article is licensed under a Creative Commons Attribution 4.0 International License (CC BY).

\section{Introduction}

An excerpt from our data reads:

In the mid-90s, when I worked at the social services unit, one of my clients lived with her family in a mould-infested house. She asked me "what shall I do?" and my first thought was: "What has happened?"... When I started [as a social worker] in the 80 s, I would have called the landlord and scolded him. This was sort of the culture in the 80s. And then I thought, if this had been the 70s, they would have closed the bloody office and taken to the streets demonstrating, complaining about these oppressive landlords....And in the 90s one asks oneself: "What shall I do?" And now, it has gone even further... today they do not even get apartments....An enormous shift... to the advantage of the landlords. (Leo, social worker)

The design of the welfare structures is of pivotal importance for combating homelessness and ensuring people's right to housing. The number of homeless people and the nature of their situations is a telling story about 
the actual workings of a country's welfare regime. Whose needs do the social work practices reflect, and whose are being neglected?

Several researchers have described how social work historically has grown from "empty spots" stringently surrounded and defined by external pressures and societal interests that (today) may be considered peripheral to social work (cf. Beronius, 1994; Fox-Piven \& Cloward, 1972; Polanyi, 1944; Villadsen, 2004). Social work has always, albeit in different designs, been a practice partly or wholly defined by societal pressure. In fact, Villadsen (2004) highlights social work practice as an analytical entry gate into understanding the "social contract," i.e., the rights and obligations of groups and individuals, in society. In this sense, social work practice is a clear signal of the forces that dictate society. It is within social work practice that the dividing lines between citizen and human, between productive and non-productive, and between rights and obligations, etc., are drawn (Villadsen, 2004). Social work with homelessness can be considered most central from this point of view because the lines drawn determine whether an individual will have a place to live in or not.

Here, we will analyse social work with those experiencing homelessness as described to us by social workers and others working in social welfare today, by highlighting practice in the light of broader societal structures and demands. We will focus on how social work practice constitutes durable homelessness in accordance with institutional demands (cf. Tilly, 1999).

\section{Background}

The municipalities in Sweden formally self-govern social welfare. During the 1980s, Sweden's universal social welfare was dictated by market logics (Sunesson et al., 1998), which had an important impact on social work with individual clients. Problems that had been regarded as structural were suddenly met with individual interventions and increased marketisation of housing policy (Sahlin, 2017; Swärd, 2020). Political pressure to deregulate the housing stock and sell parts of public housing to for-profit property owners transformed the housing stock from being a municipal political tool used to ensure everyone's right to housing into a housing market. However, ensuring housing for its inhabitants was still a municipal responsibility. Acute interventions, such as shelters, were re-introduced as part of the social workers' palette of possibilities for "helping" the homeless client (Knutagård, 2007). Researchers claimed that social housing policy had failed and pointed to increasing inequalities, e.g., differences in health and income, as contributing factors. Increasing polarisation, housing shortages, and segregation characterise this era (Clark, 2013).

As of today, there is a shortage of affordable housing for a large segment of Swedish society. Some groups in Sweden are (more or less) permanently excluded from the housing market for reasons that are not strictly finan- cial, while other groups are at risk of exclusion due to high property prices and rents that are unaffordable for many (Listerborn, 2018; Swärd, 2020). There are 0.38\% newly built apartments per capita in Sweden, which implies that population growth has far surpassed the production of new housing (Knutagård, 2018). In Sweden, compared to the other Nordic countries, a unique system has evolved for the provision of housing for people experiencing homelessness (Benjaminsen et al., 2020). Known as the secondary housing market, this system can be seen as social housing by stealth (it being invisible or hidden). It consists of apartments spread out within the ordinary housing market. The social services let the apartments from housing companies (predominantly public, but also private) and then sublet the apartments to their clients. This type of contract is called a social contract. The lease often runs for one month at a time with a notice period of one week. Sweden's most recent (2017) national homelessness count showed that there were 34,000 people experiencing homelessness - half of them within the secondary housing market. The national homelessness definition is divided into four situations: (1) acute homelessness, (2) institutional care and category housing, (3) long-term housing solutions (e.g., the secondary housing market), and (4) short-term insecure housing solutions (National Board of Health and Welfare, 2017).

The consequence of this system is that, even though the household lives in an ordinary apartment, they can quickly end up going back into a more acute homeless situation. Less than $10 \%$ of the tenants can take over their (first-hand) contract within a year (Knutagård, 2019; Knutagård et al., 2020). Research has shown that this system generates other types of housing alternatives underneath the secondary housing market (Knutagård, 2009; Löfstrand, 2005; Sahlin, 1996). Together, these different types of housing alternatives constitute the socalled staircase model where the client is expected to climb, step-by-step, in order to become "housing ready" and to progress to the end goal of an independent apartment with a first-hand contract (Sahlin, 2005). However, there are alternatives. The introduction of Housing First (HF) as an alternative way of working to end homelessness should, in the Swedish context, be seen as a niche solution when compared to the wider secondary housing market and the staircase model. Only 21 out of 290 municipalities in Sweden have implemented HF services, and in most municipalities, the HF services are small in relation to the other housing alternatives that the municipalities use (e.g., shelters, transitional housing, training flats, etc.; see Pleace et al., 2019).

\section{Methods}

\subsection{The Case of Lysboda}

Lysboda is a medium-size municipality with around 60,000 inhabitants hosting industrial companies and 
service companies alike. As with all Swedish municipalities, Lysboda witnessed the introduction of public housing companies and state-regulated rents in the 1940s and the deregulation of the housing stock in the 1990s (Sahlin, 1996).

Around 10 social workers work at the adult unit of the Social Services in Lysboda, mainly involving work with aid assessments of support, treatment, and housing for individuals with substance abuse. Like many places in Sweden, the issue of housing is constantly relevant, and it is difficult to find housing for those in need. A few years ago, a group was appointed that solely works with housing issues. The housing group reports to the unit manager. The housing group consists of four more employees: a housing coordinator who has a more prominent role in the negotiations with the housing companies and the overall responsibility for housing, a housing secretary who has a shared position between the municipal social services, the municipal housing company, and two administrative staff who have responsibility for a few contracts signed through the social services.

Today we find great variations between the local housing markets in Swedish municipalities. In some, all public housing has been sold, and in others, the public housing companies have a very large share of the rental market (Grander, 2018). In Lysboda about $1 / 3$ of the tenancies are owned and managed by the city's housing company, still the largest property owner in the city.

\subsection{Material and Assessment of Analysis}

The material for this article was collected as part of a case study on the de-implementation of efforts to combat homelessness and deal with mental illness based on recommendations in national guidelines. The municipal selection was based on the willingness and ability of municipalities to take part in the study, given that they had implemented or were about to implement HF or Individual Placement and Support (IPS). The municipality in this case was about to implement $\mathrm{HF}$ and, as we were involved, we tried to find a baseline of the current state of affairs regarding their social work with homelessness. This study is based on data from one municipality that is particularly and clearly attached to the previously established methods, characterised by qualification rituals on the part of the client, including stringent control of them. Social services in Sweden offer support to adults who, for various reasons, do not receive a housing contract themselves but how generous the social services are may vary by municipality, as does their formal organisation. Our case illustrates one way of organising social work with homelessness and shows the dependence on, and influence of, landlords in the formal and informal organisation of the social services. The reasons for being excluded from the housing market (by the landlords) can include financial difficulties, debts, mental illness, or lifestyles that make these individuals particularly unattractive to the housing market. The social services carry out investi- gations through social workers and can provide aid with initiatives that facilitate housing. The most prominent individual support in this town is 140 sublease (social) contracts for apartments, a shelter, and housing support through one team of social workers. Recently, this town decided to close the shelter and to implement HF, an initiative that promotes individual housing as the means (rather than the endpoint) of solving homelessness, provides flexible support, and promotes various aspects of well-being (Pleace et al., 2019). However, difficulties in finding vacant flats have hampered implementation.

Initially in the project, all known and available documents (guidelines, reports, decisions), as well as articles from newspapers that could be linked to efforts to combat homelessness, were collected and systematised. For this article, the first and second authors conducted 13 interviews with 21 respondents in 2020. We also took part in municipal-specific documents as pamphlets of the different contracts mentioned and municipal (written) routines regarding them, directives of the public housing company, and more general strategies set by the social welfare board. Although we do not refer to this material here, they are included in our analysis of the case. The interviewees were managers at different levels as well as politicians and employees of a housing company. We also interviewed professionals who meet clients at different levels in the studied organisations. The interviewees expressed themselves based on their professional or political roles in their work dealing with homelessness.

Seven respondents were interviewed individually (three of whom were interviewed on two occasions). Six group interviews were conducted with 2-4 participants. Some of the interviews took place in person, while others were conducted via videoconferencing due to Covid-19 restrictions. The interviews were recorded and transcribed and the material then analysed and categorised. In our interviews, we carefully followed administrative processes at the social work office and asked (historical) questions about how certain roles, groups etc. came into existence, e.g., what had certain roles been a response to and in what context. Pairing our categories-e.g., "a landlord's perspective within the social services"-and looking at the historical formal developments that were described to us, as well as the informal consequences of them, we decided to use Tilly's (1999) theorising on mechanisms that create and sustain durable inequality as our analytical tools. This case increases our understanding of the causal mechanisms that create unequal positions. From our material, we followed administrative processes at the social work office and sequentially organised instances of critical importance to understand the causes and effects of institutional demands in social work with homelessness in this municipality. Our analysis reflects all the interviews, mostly to a large extent. Cited under Section 5, Findings are trained social workers responsible for the service user's aid decision (Eva, Karin, and Lisa). These 
social workers are not part of the specialized housing group but are responsible for most aid decisions regarding adults, including housing. Within the social services, the housing group is led by a trained social worker, the unit manager Leo, but the housing group staff (including the group manager) have other backgrounds. Cited from the housing group were the group manager, Adi, who was previously a caseworker, and Annika, who holds a shared position between the specialized housing group and the public housing company. Annika has a professional background as a leisure leader but has worked with housing issues for many years.

Official functions are stated in the text, all names are fictitious, but each quotation represents a statement from a single person. The municipality name is fictitious. The study has received ethical approval in accordance with Swedish legislation.

\section{Theory}

This article draws on Tilly's (1999) work on durable inequality and uses the mechanisms put forward by Tilly to understand how homelessness is (created and) maintained in a Swedish municipality. His work on durable inequality identifies how unequal categorical pairs (e.g., citizen/non-citizen, legitimate/illegitimate) become organisationally incorporated and institutionalised, which results in organisational conditions that maintain inequality. Tilly points to four mechanisms that are active in such an organisational incorporation and institutionalisation: exploitation, opportunity hoarding, emulation, and adaptation. Tilly (1999) claims that "people who control access to value-producing resources solve pressing organisational problems by means of categorical distinctions" (p. 8). Such people serve as gatekeepers and thus delimit social systems by exclusion. Of course, there are points of transit, but the borders are (at the very least) highly controlled. These categorical pairs are often incorporated and institutionalised in organisations dealing with social welfare and are more easily incorporated if these categorical inequalities already exist, and have spread throughout society (Tilly, 1999). The exclusionary power becomes even stronger when pre-existing external categories are connected and reinforced to internally constructed categories. For instance, when gender or nationality relates to internal categories that make a distinction between "worthy" and "unworthy" clients (cf. Knutagård, 2009; Sahlin, 2020).

Exploitation and opportunity hoarding are considered two mechanisms in which paired but unequal categories are incorporated at focal organisational borders. Exploitation appears when people with access to important resources organise to increase their profit at the expense of others who may be part of profit-creation but do not partake of the profit. Opportunity hoarding appears when people gain access to a valuable resource that is possible to monopolise and that substantiates the modus operandi of the organisation (Tilly, 1999).
The two mechanisms, emulation, and adaptation, make the organisationally incorporated categorical distinctions more efficient and generalise the influence of these distinctions. Emulation occurs when established organisational patterns are copied or when social patterns are copied from one context to another. Adaptation concerns, e.g., the development of daily routines based on institutionalised categorical pairs, upholding categorically unequal structures (Tilly, 1999).

Whilst exploitation may only be used by powerful people, opportunity hoarding, and emulation may be used by less powerful people if their actions are accepted by those in power. People who create durable inequality often aim at securing profit by either exploitation, emulation, or both (Tilly, 1999).

In our interviews, the respondents give reasons for why they work or do something in a certain way (Tilly, 2006). This is what Scott and Lyman (1968) call "accounts." When people give reasons, they generally use different types depending on the situation. Tilly (2008) distinguishes between for different types of reason: conventions, codes, technical accounts, and stories. People also use different reasons depending on the relationship to the receiver. Reason-giving confirms, negotiates, establishes, and transforms relations between the person who gives a reason and the receiver (Tilly, 2008).

\section{Findings}

\subsection{Exploitation}

The aftermath of Lysboda shows how the landlords in Lysboda have exploited the emerging housing market by denying more people and new groups of people the right to housing, thereby referring these people to the social services. Having the social services ask for apartments for tenants instead of having to deal directly with them has meant that the housing companies have managed to pass this risk onto the social services. A secondary housing market has been established in Lysboda where the social services are the holders of the master lease (the first-hand contract, and thus are the holders of responsibility) a situation in which the housing companies avoid normal accountability by transferring these risks to the social services. Although around $40 \%$ of the clients living in the second-hand apartments are considered selfsufficient by the municipality and in no need of support other than housing, the transfer of risk from the landlords to the social services creates conditions that make these people social service clients. In addition, for other more traditional social service clients to access housing, special contracts are formulated involving stringent control of the tenants. This is the exploitation by the housing company: The closure of access to housing for new groups of people to gain stability by transferring risk and decreasing costs that were previously considered normal risks for (any) housing company. In addition, this 
also concerns increased control over (some) clients who are subject to special contracts that are far more insecure and involve Social Services monitoring the client (cf. Wirehag, 2021).

\subsection{Opportunity Hoarding and Emulation}

A few years ago, a group within the social services was appointed that works solely with housing issues. The housing group reports to the unit manager and is led by a group leader who previously worked as the principal social worker. In addition to these management functions, the housing group consists of four more employees: a housing coordinator (who has a prominent role in the negotiations with the housing companies and the overall responsibility for housing), a housing social worker (who has a shared position between the social services department in the municipality and the municipal housing company), and two administrative staff (with responsibility for a few contracts signed through the social services). The housing group emerged almost organically, but once in place it is clear how the hoarding of apartments by the housing group and the closing of borders (information/negotiation) between (other) social workers and housing companies placed the housing group in a particularly influential position within the social service organisation. Although most in the housing group are not trained social workers, the group dictates what social work with homelessness in this municipality is. The trained social workers get orders for decisions from the housing group and must formally write the decisions.

Social work with homelessness, in this as in many Swedish municipalities, has emulated a social order building on an external unequal categorical pair that appeared relatively recently, as people with no or minor social problems became excluded from the regular housing market. Having no apartments of their own, the social services are highly dependent on the goodwill of the housing companies (cf. Wirehag, 2021). The social services in our case negotiated with the housing companies on their terms, having to rent apartments from landlords to sublet to this newly excluded group, thus incorporating this external categorical inequality into the routines of the social services. In addition, negotiating on the terms of housing companies in this municipality meant that an internal unequal categorical pair was activated in which individual service users were referred to as being worthy or unworthy during the Social Services' communication with landlords.

\subsection{The Making of a Client}

The social services identify and interact with individuals in need through applications, registrations, or the on-call route (application on-site), such assignments are then distributed to caseworkers by a group leader. When a social worker is given an assignment that involves a person who needs a home, the social worker decides roughly to "investigate the possibility of a social contract." In concrete terms, the social worker adds the individual's personal identity number to the housing group, which contacts various landlords with a request for an apartment. Here, the landlords can be offered various guarantees, such as that the social services will inspect the apartment weekly and/or that the apartment is rented with a sublease contract. In cases where the social services inspect apartments weekly, the right of occupation has been signed over to the social services after the person has signed a master lease (first-hand contract) with the municipal housing company. Such an agreement implies that the resident must accept that the social services have keys to the resident's apartment. The resident must also accept weekly inspections of the apartment executed by caseworkers (who report that many of the residents are not home when they inspect the apartments). In consideration of families with children, the caseworkers try to agree inspection times with the residents. In this way, the individual moves from being a person in need of housing to becoming a service user and client who must accept that the authorities interfere with their self-determination.

In Lysboda, this path to a master lease is lined by steps that subject the client to a strong screening with the need to pass multiple qualifications. Such steps include accepting and undergoing treatment, accepting that they sign away their right of possession, which means being able to accept and handle visits from social services who can enter the apartment with a key. Such steps extend far beyond what other tenants must accept. The service user must show that they are "housing ready" to, later on, maybe, receive a contract of their own. Here, we find sharp similarities to the staircase model described by, e.g., Sahlin (1996), Löfstrand (2005), and Knutagård (2009), and the recommendation, in the Swedish national guidelines, is that they should be eliminated (National Board of Health and Welfare, 2018).

If a landlord accepts a negotiated offer, the social worker decides on the signing of the contract. This is how one social worker describes the process:

An order for a decision comes in [from the housing group]....Some questions have been asked about this person....Then they investigate [if] everything is ready [and] ask what decision I will make... and a bit in the form of what kind of thing it is, should it be a sublease or not, there can be a discussion of whether it should be a sublease or inspections and then they [the housing group] come and decide something. (Lisa)

The formulation of the agreement is thus not based on the service user's needs (other than a need for a home) or any other assessment made by social workers, but rather is dictated by the housing group, which justifies its influence on the decision by referring to the requirements of the housing companies. The housing 
group, as the housing companies' extended arm, has decisive influence over whether the agreement signed shall be a master lease or sublease, and whether the right of possession shall be negotiated, and whether the social services shall accept the responsibility for inspecting the apartment weekly. This process may also involve how the social workers formulate the care plans, as the social worker Eva explains: "Sometimes, the care plans come back because sometimes they [the housing group/housing companies] didn't think they were good."

\subsection{Helping is Negotiating}

The housing coordinator, Adi, with a central position in the housing group at the social services department, along with his colleague Annika, explains the hardship of negotiating apartments:

\section{Adi: We have a few names that, like, "no." \\ Interviewer: They are a bit judged in advance?}

Annika: There may be someone working in a housing company who has a relative who knew someone and knows what he did in 1982....No, he will not have an apartment.

Adi previously worked as a case manager at the social services department and explains that his role has changed: As a caseworker, he mainly "chased homes." When he was new in his position a few years ago, he and a few colleagues had a serious talk with the housing companies:

We realised that if we were to get any apartments, we had to think about how we conduct our work.... [We have to] be honest [and] not deceive [the landlords], because it is so easy to say that I have got one here who is well-behaved when it is actually the opposite....We have a few [who cannot get a contract], they live with different friends, perhaps committed some petty crime, have been imprisoned for a while or gone for treatment for a while, like in and out all the time. (Adi)

Adi also explains his own role in focusing on the client when dealing with landlords. Labelling a client, or creating internal categories like "well-behaved," or "the opposite," is at best moralising over someone's past actions, while at worst, it is reproducing a personal stigmasometimes perhaps both. Using such distinctions is a typical example of emulation, using the categorically unequal pair of the housing companies, incorporating these distinctions into the work of the social services with homelessness. While one would imagine that the negotiations between actors from the social work department and landlords would focus on the form and extension of support that the social work department can offer, the negotiation seems rather to focus on the per- sonal characteristics of the client. Are they well-behaved or not? It is probably not in the interest of some clients that their names be mentioned, because the mere act of naming can apparently exclude them from the housing market permanently.

The landlords and the housing group act upon harmonising and emulating logics, and the housing group has become a means by which the housing companies may reject certain individuals and delegate risk (that would otherwise be a standard part of being a housing company) to the social services.

As we shall see, the reasons the social workers give about social work with homelessness and their decisions are not only supportive and preventive in relation to landlords, but also controlling towards clients who meet the demands of landlords. While some clients are provided with a contract on conditions that seem to mainly serve the housing companies, others are completely excluded, and the social services, having exhausted their resources on clients provisionally accepted by the housing companies, have no tools for integrating the most marginalised into the housing market. Adi's statements also show that it is the sharing of very specific information, such as names and internal categories that makes such exclusion possible.

The housing group describes itself a little jokingly as the "landlord group" that "matches apartments as much as possible." They explain that they receive assignments from the social workers:

Adi: We have a queue of people who need help, and if we get in on a one-room apartment, it is not, like, the first in line, here's yours, but rather we look at who is this apartment most suitable for.

Interviewer: What do you look at then?

Annika: We look at the area, what we know about the client and how they would best succeed or fail, that's sort of how we think.... If we have a substance abuser for example who is heading out, we don't want to put him in a house where we already know that a known substance abuser lives or in an apartment next door.....Likewise, we have contact with landlords who then say no substance abuse in their buildings. We do not want anyone with a history of substance abuse so.

Annika holds a position divided between the social services' housing group and the municipal housing company. At the municipal housing company, she is part of a team that handles social housing issues. Here she works together with an investigator and a housing coordinator. Her duties are primarily to monitor disturbances in the municipal housing company's apartment holdings. She describes the work as eviction prevention because she is the one who reports the disturbances to case officers at the housing company. Annika herself decides on 
the taking of various actions: Should a warning letter be sent? Has a problem gone so far that it is time for an eviction? Annika reports to investigators at the housing company who then carry out her decisions. Her position is a bridge between the housing company and the social services department. Her office is at the social services department, but she has access to the municipal housing company's registers (including the history of the residents) and can, for example, quickly see if anyone is behind on their rent. Annika explains the benefits of having access to the public housing company's register of their tenants and previous tenants: "I can easily look up $\mathrm{NN}$, has he paid his rent? And I also have the payment history of NN."

The fact that she has dual roles is problematic because she is the one responsible for preventing evictions at the same time as being the one who decides upon consequences, in terms of warning letters and/or evictions. Annika's position exemplifies the paradox of the social worker: They are expected to be helping and supportive, but at the same time, controlling-and in this case, even penalising (cf. Järvinen \& Mik-Meyer, 2003). The question arises whether Annika is a gatekeeper, deciding who is to be provided for and who is not, who is to stay in their home and who is to be evicted. From this situation, as is a general tendency in our data, professional social workers are not the ones defining what social work (with homelessness) "is," nor are they the ones protecting vulnerable clients at risk of becoming homeless.

This case indicates that the organisation of social work has evolved over time having been influenced by a broad range of demands through which social workers have had to navigate. Although our material shows that some of the professional social workers still try to make sense of their daily activities and the results thereof, others are more critical. Sahlin (2004) emphasises that the Swedish state has not intervened enough to end homelessness and presses the fact that persistent homelessness is the result of poor governance. Situating our case in its proper (political) context sheds light on the position of professional social workers, and how their social work practices with the homeless are dependent on the surrounding society.

\subsection{Monitoring the Client}

When we talked about the various contract types, some social workers reacted to the abuses connected to the situations where the tenant must give up their legal right of possession to get an apartment:

It is a damned abuse actually. To be able to go into somebody's home with a key. Imagine, you can put yourself into it.... But of course, it is also a chance and an opportunity....But it is a check that you do and only a check. (Karin)
At the same time, there is a more pragmatic attitude that accepts the prevailing (power) structures that demand the service user's submission to housing companies and the Social Services' rules:

It is nonetheless a check. It is still a check and so like... and actually an opportunity to check in on them, that their situation is OK, that we can see it. Because it is often people who have... had substance abuse and then we get a chance to see that, oh, now things are beginning to go wrong. (Eva)

Among social workers, some are strongly critical of the municipality's various housing options whilst there are others who instead describe them positively, thereby legitimising them as elements of social work. They give accounts of their actions that can be justified or excused with the help of organisationally anchored reasons (Knutagård, 2009; Scott \& Lyman, 1968; Tilly, 1999, 2006). One way of justifying the use of such housing options is to refer to prevailing power structures: "It is actually the control that gives them [the service users] the contract; without the control, they would have never been able to live there, not a chance" (Eva).

The social services department does not own any housing of its own. The influx of apartments for the social services' clients is dependent on the goodwill of the housing companies. In this way, we can see how Tilly's (1999) causal mechanisms-exploitation, opportunity hoarding, emulation, and adaptation-come into play. The housing companies control the resources, the social services try to get access to housing, but the relationship between the actors activates emulation. The social services emulate the procedures of the housing companies and adapt to their ways of working to secure their niche so that housing can be obtained. The housing companies are the ones who benefit most from the relationship. This relationship is nothing new or unique to Lysbod. Sahlin (1996) drew attention to the same problem 25 years ago. But it does elucidate how the secondary housing market has become institutionalised. The social workers say that the housing companies exploit their position of power:

The landlords use it to the max....Yeah, they see a chance. So, it is wow. Now you are about to be evicted, but if you get a sublease through the social services department then you can keep living there. So, they do see a chance in this. (Karin)

And despite the prevailing power structures, the social workers are critical of the housing companies' attitudes:

It is more of a... social problem....You can have SEK 15,000 [EUR 1,479] in debt and no new ones since then, you are not eligible to live with us....What the hell is that....[It] may, after all, be a 20 -year-old 
debt....[There are] unreasonable requirements today to be able to have a human right like a home. (Karin)

\section{Conclusion}

This article's point of departure was the recent changes in housing policies with the marketisation of housing causing increased homelessness. New groups of people are becoming service users due to their difficulties accessing a flat on their own. This article aimed to explore how the organisation of the municipal social work has turned into a means of creating and maintaining homelessness, as regards people in long-term housing solutions (e.g., the secondary housing market), situation 3 in the national homelessness definition, but also people in acute homelessness (situation 1), institutional care and category housing (situation 2), and those in short-term insecure housing solutions (situation 4) who may be excluded from housing on the basis of being unworthy. If offered an apartment, service users in any of these situations, but more often in situations 1,2 , and 4 may be subjugated to control and monitoring by social services (cf. Wirehag, 2021). The article was based on a case study in a Swedish city. Empirical data consisted of interviews with staff and documents from the social services and the public housing company. The analytical tool used here was Tilly's "categorical inequality," using exploitation, opportunity hoarding, emulation, and adaptation. The results showed the dependency of the social services on external actors, and the problematic consequences both for tenants and for the work at the social services, where the requirement that they control their clients has become normalised.

In this final discussion we want to highlight three main conclusions: (1) A power relationship between the social services and landlords has affected the organisation of the social services; (2) the exclusion of new groups from the housing market is reinforced by the social services signing contracts with landlords to sublet to this group; and ( 3 ) the effect of this is that the relationship between the landlords and the social services is maintained even though groups who traditionally turned to the social services for housing support may have it permanently denied, and that which is offered often comes with far more insecurity and monitoring than is experienced by ordinary tenants.

The relationship between the housing companies and the social services is a relationship of power (on the part of the housing companies) and dependence (on the part of the Social Services). Our case demonstrates how housing companies in this municipality exploit this power to transfer the risk that is normally associated with housing companies onto the social services.

New groups of people were excluded from the housing market and turned to the social services for help. The response to the increased pressure was to form a specialised housing group and to only allow this group to deal with the housing companies when acquiring apartments. This group felt they needed a new take on things and had to win back the trust from housing companies to negotiate for apartments. To do so, this group accepted that there were worthy and unworthy (potential) apartment-holders among their service users and had put an old internal (to social work) categorical inequality (worthy/unworthy) into work. In addition, an external categorical inequality, excluding new groups from housing on the regular housing market, was simultaneously incorporated into the organisational front lines of social work with the homeless.

By subletting to this new group which quite recently has been excluded from the general housing market, the social services emulate an external social order building on a categorical inequality in terms of access to housing. The winners are the landlords who are freed from any risk normally associated with letting apartments, as they have been transferred onto the social services. Subletting also carries costs that are borne by the service clients as they live under less safe housing conditions. Incorporating this external categorical inequality into the social services workings in this way is not only to the cost of people in this group but also the regular social service users as a traditional and internal (to social work) unequal categorical pairs (worthy/unworthy) are used to acquire apartments.

The working of external unequal categories, initially generated throughout the housing market and the exploitation of the landlords, emulated throughout the workings of the social services is maintaining inequality. However, alongside this, the incorporation and reinforcement of unequal categorical pairs along the organisational lines of the social services is also feeding inequality in terms of having access/no access to housing, generating durable homelessness, alluding to Tilly's Durable Inequality.

Our analysis illustrates how client positions are shaped and how those in need of social services' help are placed in a situation from which it is difficult to escape. Clients are categorised by the institutional demands of social work, but these institutional demands are structured by the broader context in which social work with homelessness in Sweden is situated. While social work with homelessness is a product of formal political processes and decision-making, its design is also greatly affected by informal processes and negotiations with local housing companies. In this case, the desire of housing companies to minimise their own risk by using the municipal social services has become entangled with the Social Services and has altered the institutional demands placed on the client.

\section{Acknowledgments}

We thank the Swedish Research Council for Health, Working Life, and Welfare for funding this research. We also want to express our gratitude to those who participated in the interviews on which this article is based. 


\section{Conflict of Interests}

The authors declare no conflict of interest.

\section{References}

Bengtsson, B. (2013). Sverige-Kommunal allmännytta och korporativa särintressen [Sweden-Municipal public benefit and corporate special interests]. In B. Bengtsson (Ed.), Varför så olika? Nordisk bostadspolitik i jämförande historiskt ljus [Why so different? Nordic housing policy in a comparative historical light]. Égalité.

Benjaminsen, L., Dhalmann, H., Dyb, E., Knutagård, M., \& Lindén, J. (2020). Measurement of homelessness in the Nordic countries. European Journal of Homelessness, 14(3), 159. https://www.feantsaresearch.org/ public/user/Observatory/2021/EJH_14-3_A7_ v02.pdf

Beronius, M. (1994). Bidrag till de sociala undersökningarnas historia eller till den vetenskapliggjorda moralens genealogi [Contributions to the history of social research or to the genealogy of scientific morals]. Symposium.

Clark, E. (2013). Boendets nyliberalisering och sociala polarisering i Sverige [Housing neoliberalization and social polarization in Sweden]. Fronesis, 42/43, 151-170.

Fox-Piven, F., \& Cloward, A. R. (1972). Regulating the poor: The functions of public welfare. Random House.

Grander, M. (2018). For the benefit of everyone: Explaining the significance of Swedish public housing for urban housing inequality [Doctoral thesis, Malmö University]. Malmö University Electronic Publishing.

Järvinen, M., \& Mik-Meyer, N. (Eds.). (2003). At skabe en klient-Institutionelle identiteter $i$ socialt arbejde [Creating a client-Institutional identities in social work]. Hans Reitzels.

Knutagård, M. (2007). Bostadslös! Lokal politik och praktik [Homeless, local policy and practice]. In C. H. Löfstrand \& M. Nordfeldt (Eds.), Att bedöma, förklara och åtgärda hemlöshet [To assess, explain and remedy homelessness] (pp. 112-130). Gleerups.

Knutagård, M. (2009). Skälens fångar: Hemlöshetsarbetets organisering, kategoriseringar och förklaringar. [The prisoners of reason: The organizations, categorizations and explanations of homelessness work]. Égalité.

Knutagård, M. (2018). Homelessness and housing exclusion in Sweden. European Journal of Homelessness, 12(2), 103-119.

Knutagård, M. (2019). Ekonomiskt bistånd och hemlöshet [Income support and homelessness]. In T. Hjort (Ed.), Det yttersta skyddsnätet: Om arbete med socialbidrag [The outermore safety net: About work with income support] (pp. 223-245). Studentlitteratur.

Knutagård, M., Kristiansen, A., Larsson, K., \& Sahlin, I. (2020). Homelessness. Research Briefs, 14, 1-8. https://forte.se/app/uploads/sites/2/2020/09/

forskning-i-korthet-en-hemloshet.pdf

Knutagård, M., \& Nordfeldt, M. (2007). Natthärbärget som vandrande lösning [The shelter as a recurrent solution to homelessness]. Sociologisk forskning, 4, 30-57.

Listerborn, C. (2018). Bostadsojämlikhet. Röster om bostadsnöden [Housing inequality. Voices on housing shortages]. Premiss förlag.

Löfstrand, C. (2005). Hemlöshetens politik: Lokal policy och praktik [The policy of homelessness: Local policy and practice]. Égalité.

National Board of Health and Welfare. (2017). Hemlöshet 2017: Omfattning och karaktär [Homelessness 2017: Extent and character].

National Board of Health and Welfare. (2018). Nationella riktlinjer för psykosociala insatser vid schizofreni och schizofreniliknande tillstånd [National guidelines for care and support of schizophrenia and similar conditions].

Pleace, N., Baptista, I., \& Knutagård, M. (2019). Housing First in Europe: An overview of implementation, strategy and fidelity. Housing First Europe Hub.

Polanyi, K. (1944). Den stora omdaningen [The great transformation]. Studentlitteratur.

Sahlin, I. (1996). På gränsen till bostad-Avvisning, utvisning, specialkontrakt [On the border of an apartment-Eviction, deportation, special contract]. Arkiv.

Sahlin, I. (2004). Central state and homelessness policies in Sweden: New ways of governing. European Journal of Housing Policy, 4(3), 345-367.

Sahlin, I. (2005). The staircase of transition. Innovation: The European Journal of Social Science Research, 18(2), 115-136.

Sahlin, I. (2017). Bostadsmarknad, bostadspolitik och hemlöshet [Housing market, housing policy and homelessness]. In H. Swärd (Ed.), Den kantstötta välfärden [Welfare on the edge] (pp. 157-192). Studentlitteratur.

Sahlin, I. (2020). Moving targets: On reducing public responsibilities through re-categorising homeless people and refugees. European Journal of Homelessness, 14(1), 27-54.

Scott, M. B., \& Lyman, S. M. (1968). Accounts. American Sociological Review, 33(1), 46-62.

Sunesson, S., Blomberg, S., Edebalk, P., Harrysson, L., Magnusson, J., Meeuwisse, A., Petersson, J., \& Salonen, T. (1998). The flight from universalism. European Journal of Social Work, 1(1), 19-29.

Swärd, H. (2020). Hemlöshet $i$ Norden-Utveckling av nordisk bostadspolitik [Homelessness in the Nordic countries-Development of Nordic housing policy]. Nordens välfärdscenter.

Tilly, C. (1999). Durable inequality. University of California Press.

Tilly, C. (2006). Why? What happens when people give reasons... and why. Princeton University Press. 
Tilly, C. (2008). Credit and blame. Princeton University Press.

Villadsen, C. (2004). Det sociale arbejdes genealogi om kampen for att gøre fattige og udstødte till frie mennesker [The genealogy of social work on the struggle to make the poor and excluded to free people]. Hans Reitzels.
Wirehag, M. (2021). Gatekeeping, managing homelessness and administrating housing for the poor: The three functions of local housing services for people experiencing homelessness in Sweden. European Journal of Homelessness, 15(1), 83-105.

\section{About the Authors}

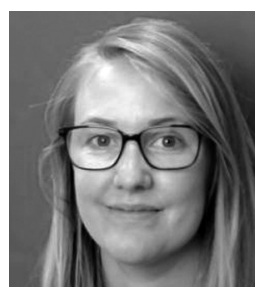

Kristina Carlsson Stylianides is a PhD Candidate at the School of Social Work, Lund University. She is especially interested in public organisations as intersection points that organize the relations between individuals and society. She is part of the project "Take away-Disinvestment of Established Methods When Implementing New Psychosocial Interventions for Homeless People and People with Mental Health Problems." Within this project, she is currently working on identifying denominators that are crucial when implementing Housing First and Individual Placement and Support.

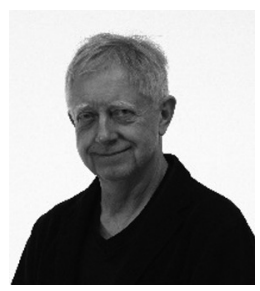

Verner Denvall is Professor in Social Work at Lund University and was previously Professor at the Department of Social Work at Linnaeus University. His work is related to evaluation and planning with a focus on issues of implementation and de-implementation of interventions to combat inequality and domestic violence. He has published articles together with colleagues on meta-governing EBP and motivational interviewing, and is currently co-editing a book on participation.

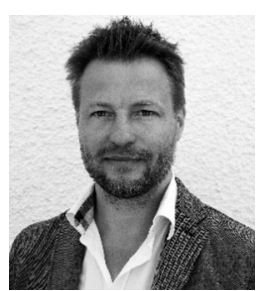

Marcus Knutagård is an Associate Professor at the School of Social Work, Lund University. His research interests include housing policy, homelessness, and the importance of place for how social work is organised-its moral geography. Two of his ongoing research projects are "Scanian Homes: Reception, Settlement or Rejection-Homelessness Policies and Strategies for Refugee Settlement" and "Take Away-Disinvestment of Established Methods When Implementing New Psychosocial Interventions for Homeless People and People with Mental Health Problems." 